\title{
Education and Career Choices: How the School Can Support Young People to Develop Knowledge and Decision-making Skills
}

\author{
Helena Eriksson', Sara Högdin ${ }^{1}$, Anna Isaksson ${ }^{2, *}$ \\ ${ }^{1}$ School of Health and Welfare, Halmstad University, Sweden \\ ${ }^{2}$ School of Education, Humanities and Social Sciences, Halmstad University, Sweden
}

Copyright $\bigcirc 2018$ by authors, all rights reserved. Authors agree that this article remains permanently open access under the terms of the Creative Commons Attribution License 4.0 International License

\begin{abstract}
Contemporary society is characterized by rapid changes in the labor market, increased flow of information, and more opportunities to make choices in relation to education and career. Previous research has demonstrated how many young people in school don't think they get the support they need to make such choices. The overall aim of this article is to contribute to more in-depth knowledge of what kind of support and knowledge young adults describe as important in order to be able to make informed choices. This knowledge might help school to better support young people in acquiring the knowledge, skills, and attitudes in relation to their education and career choices. The article is based on interviews with 25 -year-old men and women. 23 interviews were conducted. In sum, the analysis indicates that guidance activities that aims to contribute to knowledge about the labor market, programs and courses and requirements for different education programs would probably be perceived as more fruitful by the young adults if they are organized in a combination of different levels, i.e. both as group activities (exhibitions, general information/discussion) and individual activities (personal information/discussion). Further, the authors demonstrate that roles and expectations between pupils, teachers and guidance counselors should be discussed and clarified.
\end{abstract}

Keywords Education and Career Choice, School, Guidance Counselors, Counseling, Teachers

\section{Introduction}

We live in a time characterized by constant changes in the labor market related to phenomena such as globalization and digitalization. In our knowledge-intensive and complex society, competences and skills need to be continuously developed, and young people are forced to make several choices related to education and career $[2,10,13]$. A society that is characterized by a rapid rate of change in the labor market, increased flow of information, and numerous opportunities to make choices puts high demands on young people. They have to understand the choices and opportunities available to them and how different choices and decisions can have different consequences. In this respect, for example, guidance counselors and teachers play a central role in supporting young people in their efforts to navigate this complex world. Studies have clearly demonstrated how the freedom of choice when it comes to educational and career choices can contribute to the experience of stress, pressure, and mental illness [14]. Guidance and support is also important when it comes to ensuring equal opportunities for different socio-economic groups to be able to choose under the same conditions and thus avoid young people's study and career choices being limited by their gender or by their socio-economic or cultural background [13].

According to current and previous curriculum, the schools in Sweden are obliged to support young people when it comes to education and career choices. However many schools do not pursue targeted work for this purpose because they believe they lack tools to do so. There are also a number of studies that have indicated that guidance activities sometimes do not match what the students themselves think that they need in order to be able to make proper choices. Young people express their wish to receive more active support from their guidance counselors, and sometimes they even want the counselors to tell them what to do. The young people also call for more personal instead of general information as well as more support when it comes to reflecting on their future [1, $7,5,13]$. Young people have great responsibility for their future choices, while at the same time adults in school, 
such as teachers and guidance counselors, often lack strategies to increase young people's knowledge and to support them in their choices regarding their futures. The fact that young people call for more support does not mean that adults in school should necessarily tell young people what to do and what to choose. Previous research rather indicates that young people are not sufficiently prepared to make choices and to be able to navigate among all of their available choices $[1,5]$.

The overall aim of the present study is to contribute to more in-depth knowledge of what kind of support and knowledge young adults describe as important in order to be able to make informed choices. This knowledge might help school to better support young people in acquiring the knowledge, skills, and attitudes in relation to their education and career choices.

\section{Education and Career - Choice and Decision-making According to the CIP Theory}

In this article, we take our point of departure in the cognitive information processing (CIP) paradigm [11].

The CIP theory and paradigm offers a conceptual framework for analyzing different dimensions of how individuals can become education and career problem-solvers and decision-makers throughout their whole lives. The theory concerns individual cognitive processes but as Peterson, Sampson, Lenz \& Reardon [11] state, the CIP paradigm enables us to problematize what counselors can do to enable individuals to acquire knowledge and skills that are necessary for education and career decision-making. From a CIP perspective

(...) career counseling involves providing the conditions of learning that enhance the acquisition of self and occupational knowledge, as well as the development of career problem-solving skills that transform information into satisfying and meaningful career decisions. The continued development of these capabilities is necessary for individuals to manage the inevitable occurrences of career problems that arise throughout the course of a lifetime [11, p 319].

The CIP theory is based on a three-level pyramid. Self-knowledge and occupational knowledge can be described as the foundation of the pyramid (knowledge domains). Self-knowledge includes, for example, self-awareness of your personality, interests, needs, strengths, and limitations. Previous experiences and present feelings influence your self-knowledge. Occupational knowledge, or knowledge about occupational options, concerns, for example, knowledge of the "world of work", the labor market, available jobs and the outlook for different occupations. It also relates to question such as "What skills are required?" [11].

The second level of the pyramid is the decision-making skills domain. This level is composed of five information-processing skills - communication, analysis, synthesis, valuing, and executing. In this level, information from the knowledge domains is transformed from the recognition of a problem to the implementation of a solution. The top of the pyramid consists of the executive processing domain. The skills of this domain includes, for example, self-talk.

To become independent and responsible problem solvers, individuals must also become their own best friends as problem solvers. Individuals who use and believe in positive self-talk such as 'I can learn to be a good career problem solver' or 'I know I can trust that my career decision will be the right one for me' will approach the task of career problem solving and decision making much differently than individuals who use negative self-talk such as, 'I've tried to find a good occupation many times before, but I can't ever arrive at good decisions', or 'People, like counselors or teachers, are better suited to solve my career problems than me' [11, p 327).

There are interesting social and cultural aspects of education and career decision-making and the different levels described above. Self-knowledge and occupational knowledge are not only acquired through an individual construction process, but also through social construction processes. If, for example, individuals during their childhood are exposed to restricted environments in which family, relatives, and friends perform similar work - their first-hand knowledge of the world of work will probably be quite narrow. In the executive processing domain, the self-talk might be influenced by the power relations in society. Members of disadvantaged groups might think that some career options and opportunities are not available for them and negative self-talk often can lead to inappropriate actions or to inaction [11].

\section{Method}

The empirical material analyzed in this article consists of an interview study with young adults who grew up in a small municipality in the southwest of Sweden.

\subsection{Participants}

The interviews were conducted with 13 women and 10 men, all aged 25 years. The young adults who participated in the interviews had previously participated in a questionnaire study and were asked to fill in their contact information in the questionnaire if they were willing to participate in the interview study. The questionnaires were sent out by mail in the fall of 2012 to all residents who 
grown up in the municipality and were born in 1987. Some were still living in the municipality, while others have moved outside the municipality.

The interviews were conducted in the spring and autumn of 2013. The individuals participating in the interview study were selected for the interview study based on the following categories: "Still living in the municipality and have studied or are studying at university," "Still living in the municipality and have not studied at university", "Have moved outside the municipality and have studied or are studying at university", and "Have moved outside the municipality and have not studied at university". It was not obvious in advance, how many people should be interviewed, but after about 20 interviews a so-called theoretical saturation appeared. This means that the respondents began to repeat what former respondents had said [8].

\subsection{Data Collection}

In the interview study, a semi-structured interview method was chosen in order to provide an opportunity for the interviewees to respond based on their own perspectives on career choice. The starting point of the interviews was therefore a number of predefined themes concerning support, education, and career, but the interviewees were given ample opportunity to highlight their personal perspectives [4, 12]. For example, the questions concerned: Can you tell us about why you chose your education program? What kind of information about higher education did you get from teachers and guidance counselors during your time in school? Was there somebody who influenced your choice of education?

It is important to note that the interviews covered both questions about the present and the future, but they were also retrospective in nature in the sense that some questions asked the interviewees to look back at how things had been in the past [15]. The latter is especially present in this article, which focuses on how the young adults looked back on their experiences of guidance counseling in primary and secondary school. The retrospective nature of this study entails both advantages and disadvantages. An advantage is that the young adults might have gained new perspectives on their previous situations and could relate the past to their current situation. A disadvantage is that they might have had trouble remembering how things were during their time in primary and secondary school. In other words, it is the memories that remained and the situations that made an impression that are presented in this study.

Ten of the interviews were conducted in locations that the interviewees themselves decided, which meant that the interviews took place at the respondent's workplace, home, or in a cafe. Twelve interviews were conducted as telephone interviews due to geographical reasons, and one interview was conducted via email because the respondent specifically asked for that. The time of the interview was from 30 minutes to an hour and a half. All of the interviews were digitally recorded and transcribed verbatim with the exception of the email interview and two additional interviews where the interviewees did not want to be recorded on tape. These interviews were compiled in writing.

\subsection{Data Analysis}

The data analysis began by reading the transcripts in their entirety several times. All three researchers in the project read all of the transcripts. Two researchers conducted the data analysis, and the results were discussed with the third member of the research team. The analysis continued with making notes and identifying categories in the transcripts. In the next step, some patterns started to emerge and the open categorization which consisted of several different and not very coherent categories - became characterized by more focused and selective categorization. The selective categorization resulted in categories that came to represent the empirical findings that were the most relevant to the objective of this article. The categories were based on the interviewees' descriptions of past experience of support from adults in school in terms of study and career choices and especially on the perceived lack of important knowledge needed to make autonomous decisions. It was also these descriptions that we wanted to develop in relation to our theoretical perspective and concepts. This method of analysis was based on aspects of both Fejes and Thornberg's [9] and Watt Boolsen's [16] discussions on qualitative analysis, which is by no means a simple and linear process. The interview transcripts were read several times, and categories and themes were created, discarded, revised, and finally systematized into how they are presented in this article.

\subsection{Ethical Considerations}

According to the Swedish Health Care Act (2003:460) concerning the Ethical Review of Research Involving Humans, an ethical review was not necessary in this study because no sensitive personal information was requested. However, the study still followed the informant requirement, the consent requirement, the confidentiality requirement, and the usage requirement in the ethical research principles of the Swedish Research Council. All participants were verbally informed about the aim of the study and were informed about the anonymity of their responses. All of the participants gave their informed consent verbally.

\section{Results}

The results of the interviews are presented in four 
themes: Knowledge about the labor market, Knowledge about programs and courses, Knowledge about the requirements for different education programs, and Knowledge about alternatives.

\subsection{Knowledge about the Labor Market}

The young adults in this study express a consistent picture of that they did not get sufficient knowledge about the labor market in general during their time in primary and secondary school, and several of them said that they wished that they had gotten more knowledge in their early years of primary school during class and through the teachers.

\section{No, I think that for the teachers there should be a little more talk about what you can be and what you can work with. From what I remember, we never talked about it. There are many different things you can work with that are good for society. (Miriam)}

The respondents also emphasized that they wished for clearer and more general information about the labor market and about the choices they could make, and they reported shortcomings in both primary and secondary school guidance and counseling. For example, Sandra described how her guidance counselor was vague and seemed unsure of different opportunities.

No, I do not think, I think that our guidance counselor was very vague. She did not seem very experienced, and she did not seem to have much knowledge, actually, about what one could do. (Sandra)

It became clear from several interviews that the lack of knowledge about the labor market meant that the respondents felt that it was difficult to know what kind of options they had, and this led to an uncertainty about their educational choices. A common theme among these young adults was that when they were in school they were unsure of what they wanted to do in the future.

These results show that the respondents did not think that they got sufficient knowledge about the labor market in general. The young adults expressed that such knowledge would have been valuable starting in their early years in primary school and that it should come from both their teachers as part of the classroom lessons and from their guidance counselors. Because of the lack of knowledge about the labor market in general, the respondents expressed uncertainty as a youth about what they wanted to work with in the future and what kind of educational choices they should make.

\subsection{Knowledge about Programs and Courses}

According to the young adults in this study, the knowledge that primary and secondary school students get from school personnel about different educational options consists mostly of information given shortly before they are supposed to choose their secondary school education or university courses.

Both how and when students receive information and the opportunity to discuss future career and education were raised during the interviews. Some respondents point out that the information about, and discussion of, educational opportunities could have started earlier. Jakob said, for example, that he did not have many discussions with teachers about education and secondary school choices. The few conversations he had were just before the choice had to be made.

Interviewer: The teachers, did they talk to you before the choice? Your teachers?

Jakob: Well, I do not think so. Of course, you had a class teacher, and I suppose we talked about this, but not excessively. It was, perhaps, more like when the choice of further education was getting close. Maybe then we talked a little more about it, but I do not feel that it was that much. It was not to any great extent. It felt that it was nothing, what can I say, there was not very much focus on it, actually.

Interviewer: Yes.

Jacob: Well, maybe that is the standard. There was nothing [...] One could have started up the discussion earlier, I think.

Meetings with guidance counselors took place before the choice of further education was to be made, but not everyone had such meetings. Some respondents did not remember if they had met with a guidance counselor to discuss various educational opportunities or not, and some reported not having met with a guidance counselor at all. Other said that it was difficult to get support from the guidance counselor if they did not know what they wanted to choose. Few did not contact the guidance counselor because they did not know what they wanted to do or what opportunities they had and so did not have any concrete questions for them to answer. However, those who already knew what they wanted to study or what they wanted to work with in the future reported that they had received sufficient support from their guidance counselors.

\begin{abstract}
I think she asked, what do you want to do? Then I said I did not know what to choose between these two. And then she gave me some suggestions. Then she just said to do something with equestrianism, [...] but I said, "I do not want to work in sports". And she said, "No, but you can read NV [the science program] and then get everything you need [for higher education]. (Carola)
\end{abstract}

Several respondents described secondary schools and colleges/universities inviting secondary school students to different types of exhibitions as an activity regarding 
educational opportunities offered by the schools. However, how the students viewed these events differed. The exhibitions were described as an activity where the students could ask questions about different educational programs and courses. This was mentioned by a number of respondents, but none of them believed that the exhibitions were important for their choice. For example, Jakob said that the exhibitions:

\section{We're not something I felt were essential at all.}

Some young adults in this study also talked about the exhibitions as problematic in several ways, meaning that the exhibitions did not provide sufficient information to make choices regarding future education. Ulf described the exhibitions at secondary school as not focusing on giving potential students information about the education programs, and he felt that the purpose was mainly to attract students to the various programs.

But it [the information at the exhibitions] can be a little misleading because often there is not so much information; instead, they [the science education program] had helium balloons and a flame that burned, so science should be a little cool and neat to study. They tried to attract young people that way. (Ulf)

Many respondents emphasized that they did not receive any clear information from their school about different education programs or about what different education programs might lead to in terms of careers. Some respondents also believed that the overall information they received from their schools about educational choices had not had any significant impact on their choice of education. Saga described a series of information activities she participated in during secondary school such as making collages about different educational programs and going to exhibitions - but she said:

"That was not why I chose the education I did. My choice had no connection with the information I got in secondary school."

A lack of conversations and oral information appeared as a weakness in the guidance that the respondents got in school regarding career and educational choices. For example, Sara pointed out that the information that she got was inadequate for making educational choices and that she lacked verbal information.

Sara: I thought about the fact that there should be better information about it [educational choices] because I think many people just choose anything, really.

Interviewer: What kind of information do you think they should provide and develop more around?

Sara: Well, that is, more verbal information on how the educational programs are structured. You get a little information about that, but I still do not think it is enough.

Albin also talked about the lack of verbal information and discussion by pointing out that the guidance counselors often referred to the Internet.

No, my opinion is that the guidance counselors can only say one thing, "You can read more about it on this website." (Albin)

There were, however, different views among the respondents regarding to what extent the Internet is a good source of information. Helena described, for example, that a lot of information about higher education is available on the Internet and that the school should be able to demonstrate the possibilities of finding information on the Internet.

Helena: Now you just go onto the Internet and check and search [the programs you are interested in and want to apply for]. One can find all of the courses that are available.

Interviewer: Exactly, a lot of information is on the Internet today.

Helena: So it would certainly be something you could go through in school.

These results show that the respondents would have liked more knowledge about what kinds of careers different educations might lead to. When it comes to support from guidance counselors, the respondents who did not know what they wanted to do found it difficult to get support and often did not even contact the guidance counselor, whereas respondents who already knew what they wanted to do were satisfied with the support they received. Exhibitions by schools about the education that they offered were frequently described in the interviews. However, they were not described as being important for the young adult's choices or as providing relevant information, but more as an activity to attract students to different programs. Several respondents said that they would have liked to have had more oral information and discussions in school related to knowledge about future educational choices. Many felt that there was too much focus on finding information on the Internet, although they acknowledged that knowing how to find information on the Internet is valuable. Thus, these results show that the young adults thought that the overall information they got from school did not have any significant impact on their choices regarding their future education or career.

\subsection{Knowledge about the Requirements for Different Education Programs}

The young adults described how they wished they had 
received specific knowledge of what is needed to proceed with future education. In primary school, it is about getting knowledge of the grades required to get into a particular secondary school program. In this case, such information was not seen as being problematic. The respondents got knowledge about this, for example, by talking to their guidance counselors. However, in terms of knowledge about specific requirements to move from secondary education to university education, there was a lack of both information and answers to specific questions. Some of the young adults describe how guidance counselors informed the whole class in the classroom at some occasion but they wished that the information also should be more personal.

William described the difficulty in gaining knowledge about the eligibility requirements. He had studied in a vocational program in secondary school, but early on in the program he decided that he wanted to go on to university after secondary school. He then needed knowledge on which courses he needed to take to be eligible for the university program he wanted to study. In this regard, he felt that he did not get any clear information from the guidance counselor, whom he was in contact with several times.

William: I talked a lot with the guidance counselor. I wanted her to find out precisely what I needed for [the university education he wanted to study], which was my plan at the time.

Interviewer: Did you look into this early in your secondary education, or?

William: Yes, during my first year. I checked it. [...]

Interviewer: Do you think you got good support from the guidance counselor?

William: I have to say - No. Because I asked several times, to tell me exactly what I needed. And it was always so vague, you might need this, you might need that, and yes, really, in hindsight it would have been better to have gotten on the phone and called [the university] and had it all explained. That's what I finally did.

In sum, this theme shows that the respondents found it difficult to get information and answers from the guidance counselors regarding specific knowledge they needed about the requirements to go on to higher education.

\subsection{Knowledge about Alternatives}

The respondents indicated that did not receive adequate knowledge of alternative education programs and careers. They described how if they had an idea of what they wanted to study and work with in the future they received support, but they were not given information about other possibilities.
Interviewer: Did you have any discussions with your teachers about anything, any activity, when you were talking about higher education?

Miriam: No, I was told that they knew that I wanted to become a police officer, and so the teachers knew, it felt like they thought that I would reach that goal. That's how it felt anyway.

The respondents in this study who went on to vocational training in secondary school described how there was a one-sided focus that they should be out and working in the professions they trained to be in, and in school they never talked about alternative possibilities or higher education.

No, they were pretty much focusing on, the carpentry teachers were focusing on, they probably thought that everyone studying in the program would become carpenters, so it was most focused on that. This was good, though, and they had a lot of focus on how we should get an internship, make contacts. They talked a lot about how the best way to get a job is through an internship, and that is true. After all, they were just doing their job and they probably had no thoughts that one would study at university or not. (William)

These respondents indicated that there were few discussions in school about options in the labor market or the different possibilities in relation to higher education. However, such discussions were not seen as necessary by all of the respondents, especially those who were tired of school or did not intend to go on to higher education. For example, Erik described how he did not discuss his choice to drop out of school in the ninth grade with anyone.

Interviewer: No, did you ever talk to an adult in school about the choice to drop out?

Erik: No, I did not.

Jacob described how he believed that his teachers and guidance counselors did not want to influence their students' choices and thus they were careful not to steer the students in any particular direction. However, there were descriptions from the respondents where they described feeling that they had been influenced by their teachers. In one example, Thomas described how a teacher had urged him to drop out of secondary school. A choice that he afterwards does not think was a good choice.

Interviewer: What was crucial for you finally deciding to drop out?

Tomas: Yes, it was actually my teacher who said that he believed it would be a good choice for me.

Interviewer: Was it a good choice?

Tomas: No, I do not think it was so good. 
Another example came from Miriam who described how a teacher influenced her choice in a positive way, which she was happy about afterwards.

Miriam: I remember in eighth grade, we had a PE teacher [...] when I imagined that I would become a hairdresser - do not ask me why! - and then I remember that he said to me, 'Should you really choose that? You have such good grades,' or something like that. And it got me thinking, he's actually right. [...]

Interviewer: And that was crucial for you then?

Miriam: Yes, he got me to thinking, and I thought that he was probably right. And before, I was thinking of choosing to become a hairdresser and my dad had bought me some stuff so that I could practice. So I cut my dad's hair, and he was saying he could help me open my own business, and so on. But today I'm happy because hairdressing had not really been my thing.

The results under this theme show that some of the young adults did not experience that they got sufficient knowledge about alternative education and career paths in school. They talked about how if they had an idea about their future they did not receive information about other possible paths. Another example was that those who went on to vocational training in secondary school did not receive any information about higher education, and the focus was solely on getting a job. Overall, only a few of the respondents reported having discussions about higher education in school. There was a general feeling among several respondents that their teachers and guidance counselors did not want to influencing them by talking about different options and alternatives, although there were examples in our interviews of young adults who had been influenced to drop out of school or to choose a different education than they had first thought about. However there are examples of young adults that were presented alternative educational and occupational choices.

\section{Analysis and Discussion}

This study shows that young adults express a palpable lack of support in their choices of education and career when they look back on their time in primary and secondary school. Previous studies have shown similar results concerning young people's experiences of deficiencies in meetings with guidance counselors and the need for more time to talk about their future and their career choices with adults in school and that the guidance counseling should start earlier in school $[1,7,6]$.

\subsection{Lack of Knowledge}

Our respondents reported a lack of knowledge in terms of both knowledge about themselves and the labor market in general, which is the first level of knowledge needed to support young people's career problem-solving and education decision-making skills according to the CIP theory [11]. Our respondents also reported that they did not receive adequate knowledge about the complexity that exists in the labor market, and they said that such knowledge would be valuable starting from the early years in primary school from both teachers as a part of the classroom education and from guidance counselors. Because of this lack of knowledge about the labor market, our respondents said that they had experienced uncertainty about what they wanted to work with in the future and about what kinds of educational choices they should make. This uncertainty can also be a result of a lack of clear self-knowledge and self-understanding in relation to career choices. Some of our respondents expressed, for example, that it is not easy to know what you want to do or want to work with in your future when you are still only a teenager. Some amount of uncertainty is, of course, natural. When you are young, your experiences of the world and the world of work are limited. However, some of this uncertainty might also be related to a lack of self-awareness of your personality, interests, and needs.

Our results suggest that the respondents did not get sufficient knowledge about alternatives in school. They reported that if they had an idea about their future, then they did not receive information about other possible futures. One example of this was the respondent who went on to vocational education in secondary school but did not receive any information about higher education and who said that the focus was only on getting a job. Overall, our respondents reported few discussions about higher education in school, and they described how they found it difficult to get information and answers from their guidance counselors about the specific knowledge and requirements needed to go on to higher education. This means that there is risk that the knowledge that you get as a youth related to the knowledge domains (self-knowledge and occupational knowledge) will be limited to the narrow knowledge that you get from family and friends [11] and will not be widened by other perspectives. Such a lack of information risks limiting young people's ability to find new opportunities in life and limiting their ability to act as autonomous citizens, and it risks the education system becoming the basis for the reproduction of unequal class structures in society [3].

\subsection{Lack of Decision-making Skills}

Knowledge of opportunities in the labor market and an understanding of self is complex but are fundamental for the second level in CIP theory with regards to young people's ability to make decisions. This level includes drawing relationships between young people's 
self-understanding and knowledge of occupations, and this requires knowledge from the first level of the theory [11]. The results in this study show that the young people ask for more time to talk about their future and their career choices. When it comes to support from guidance counselors, the respondents who did not know what they wanted to do found it difficult to get support, and they often did not even contact the guidance counselor, whereas respondents who already knew what they wanted to do were satisfied with the support they received. Other activities related to being able to make an educational choice that were frequently described in the interviews included exhibitions by schools about the education programs that they offer. However, these were not described as being important for the choices or as providing relevant information for making a decision, but instead were seen more as an activity to attract students. This result shows that the young adults felt that the overall information they got from school did not have any significant impact on their choice of future education. The respondent's decision-making skills were not developed through the activities organized by the schools because the activities did not give the them sufficient opportunities to communicate, analyze, and value what (little) knowledge they had about the labor market and about themselves.

This can further be understood through the feeling among our respondents that their teachers and guidance counselors did not want to influence them by talking about different options and alternatives. This resulted in that the young people did not get the opportunity to reason about their future with adults in school, which is crucial in order to develop their decision-making skills. However there are examples from the interviews of students being influenced to drop out of school or to choose a different education than they had first thought about through talks with their teachers. This shows that adults in school can be of great influence, and it emphasizes the importance that the adults are aware of how they can influence students through conversations about educational and career choices.

If young people have neither received sufficient knowledge to make proper choices nor the opportunity to discuss their choices with adults in school, it will be difficult for them to reach the third level in the CIP theory, which involves both seeing opportunities and feeling that you can make autonomous decisions in order to reach your goals.

\subsection{How to Improve Counseling from the Young Adults' Perspective}

So far, our analysis indicates similarities to previous studies. However, our empirical data also provides us with some guidance regarding how the counseling could be improved. For instance, "knowledge about the labor market" could, according the young adults, be integrated as part of the classroom lessons, i.e. a form of group activity with general information and discussions. The teachers become important actors in this manner. This activity could be complemented with more personal information and guidance from the guidance counselors.

According to the young adults, exhibitions seem to be a common activity when it comes to "knowledge about programs and courses". The young adults express that exhibitions have had limited impact on their career choices. They also find it problematic that the guidance counselors often refer to Internet instead of having a discussion with the students. Our empirical data indicates that young adults view more personal and specific information about programs and courses as necessary. However, this doesn't necessarily mean that exhibitions and information at Internet are not valuable. It could be interpreted in a different way, e.g. that general information and information received during group activities also needs to be processed in a personal way for being perceived as meaningful.

Some of the young adults knowledge expected very personal information and conversations about the "requirements for different education programs" and not only information activities in the classroom. They became disappointed when the guidance counselors were vague. We consider this example as an illustration of the importance of clarifying what expectations pupils, guidance counselors and teachers have. What responsibility do the different actors have in the guidance work? We cannot see anything in our empirical material that indicates that roles and expectations are discussed and clarified which we believe is a crucial part in all the three levels of the CIP-pyramid (knowledge domains, decision-making skills domain and executive processing domain).

In relation to our previous theme "Knowledge about alternatives" it is clear that the young adults expected more guidance and support from teachers and counselors. We argue that one of the most important aspects of this theme is to highlight how some of the young adults experienced that their teachers and guidance counselors did not want to influence them by talking about different options and alternatives. As we discussed earlier, it is likely that this had a negative impact on the young adults ability to develop their decision-making skills and be able to make well-informed decisions. However, it is also important to notice that not talking about alternatives is also a way to influencing young people, e.g. to drop out of school as we demonstrated earlier.

\section{Conclusions}

In sum, this article has confirmed previous studies regarding how young people wish to receive more active support from their guidance counselors. However, the 
article has also contributed with some in depth thoughts from some young adult's perspective about how guidance and counseling could be organized and improved.

Our analysis indicates that activities that aims to contribute to knowledge about the labor market and knowledge about programs and courses (which are related to the knowledge domain in the CIP theory) would probably be perceived as more fruitful if they are organized in a combination of different levels, i.e. group (exhibitions, general information/discussion) and individual activities (personal information/discussion) and involve both teachers and guidance counselors. This is also the case when it comes to "requirements for different education programs". Even though it is not expressed so explicitly in relation to "knowledge about alternatives" it is likely that the same organization with group and individual activities with general and personal information is preferable.

Our analysis demonstrates that roles and expectations should be discussed and clarified. What responsibility do I (as a pupil/teacher/guidance counselor) have in relation to development of self-knowledge, occupational knowledge and decision-making skills?

Finally, there is a need for more discussions about how teachers and guidance counselors could be more aware of the fact that their cautiousness regarding talking about alternatives and influencing the young people also is a way to actually influence future and career choices.

\section{Acknowledgements}

The authors would like to acknowledge the municipality of Falkenberg, Region Halland, and the County Administrative board in Halland, Sweden, for financing this study.

\section{Conflict of Interest and Funding}

This study was funded by the municipality of Falkenberg, Region Halland, and the County Administrative board in Halland, Sweden. The authors report no conflict of interest. The authors alone are responsible for the content and writing of the article.

\section{REFERENCES}

[1] P. Akos, P, T.R. Konold \& S. Niles. A career readiness typology and typical membership in middle class school. Career Development Quarterly. 53, 53-56, 2004.

[2] M. Allvin, G. Aronsson, T. Hagström, G. Johansson \& U. Lundberg. Gränslöst arbete - socialpsykologiska perspektiv på det nya arbetslivet. Liber, Stockholm, 2006.

[3] P. Bourdieu \& J. Passeron. Reproduktionen: bidrag till en teori om utbildningssystemet. Arkiv förlag, Lund, 2008.

[4] A. Bryman. Samhällsvetenskapliga metoder. Liber, Malmö, 2002.

[5] J. Dresch \& A. Lovén. "Vägen efter grundskolan". In Lundahl, L. (red.). Att bana vägen mot framtiden. Karriärval och vägledning $\mathrm{i}$ individuellt och politiskt perspektiv. Studentlitteratur, Lund, 2010.

[6] J. Dresch \& A. Lovén. Vägledning i förändring. Malmö Högskola, 2003.

[7] H. Eriksson, S. Högdin, A. Isaksson \& A. Urbas. Strategier för höjd utbildningsnivå. Slutrapport från en studie i Falkenbergs kommun. Högskolan i Halmstad, 2014.

[8] P. Esaiasson. Metodpraktikan: konsten att studera samhälle, individ och marknad. (3. [rev.] uppl.) Norstedts juridik, Stockholm, 2007.

[9] A. Fejes, \& R. Thornberg (red.) Handbok i kvalitativ analys. (1. uppl.) Liber, Stockholm, 2009.

[10] L. Lidström. En resa med osäkra mål. Unga vuxnas övergångar från skola till arbete $\mathrm{i}$ ett biografiskt perspektiv. Doktorsavhandlingar inom den Nationella forskarskolan i Pedagogiskt Arbete Nr 18. Umeå: Umeå universitet, 2009.

[11] G W. Peterson, JR. Sampson, J G Lenz \& R C. Reardon. "A Cognitive Information Processing Approach to Career Problem Solving and Decision Making", In Brown, Duane. Career choice and development. Duane Brown and associates. 4th ed. The Jossey-Bass business \& management series, 2002.

[12] A. Ryen. Kvalitativ intervju - från vetenskapsteori till fältstudier. Liber AB, Malmö, 2004.

[13] Skolinspektionen. Studie- och yrkesvägledning i grundskolan. Kvalitetsgranskning Rapport 2013:5.

[14] SOU. (2006:77). Ungdomar, stress och psykisk ohälsa Analyser och förslag till åtgärder. Stockholm: Fritzes.

[15] J. Trost. Kvalitativa intervjuer. Studentlitteratur, Lund, 2005.

[16] M. Watt Boolsen. Kvalitativa analyser: [forskningsprocess, människa, samhälle]. (1. uppl.) Gleerups, Malmö, 2007. 